\title{
Burden of comorbidities among Japanese patients with atrial fibrillation: a case study of dyspepsia [Corrigendum]
}

Kinoshita Y, DiBonaventura M, Rossi B, Iwamoto K, Wang

ECY, Briere JB. Clin Exp Gastroenterol. 2013;6:51-59.

On page 54 , in the second paragraph, line 6, note that " $26.65 \%$

versus $17.02 \%$ " should be " $29.65 \%$ versus $17.02 \%$ ".

\section{Publish your work in this journal}

Clinical and Experimental Gastroenterology is an international, peerreviewed, open access journal, publishing all aspects of gastroenterology in the clinic and laboratory, including: Pathology, pathophysiology of gastrointestinal disease; Investigation and treatment of gastointestinal disease; Pharmacology of drugs used in the alimentary tract;
Immunology/genetics/genomics related to gastrointestinal disease. This journal is indexed on CAS. The manuscript management system is completely online and includes a very quick and fair peer-review system. Visit http://www.dovepress.com/testimonials.php to read real quotes from published authors.

Submit your manuscript here: http://www.dovepress.com/clinical-and-experimental-gastroenterology-journal 